\title{
PENGARUH LITERASI KEUANGAN TERHADAP KEPUTUSAN INVESTASI DENGAN PERILAKU KUANGAN SEBAGAI VARAIBEL MODERASI
}

\author{
Adilla Fakrian Audini 1)*, Abd.Mansyur Mus ${ }^{2)}$, Herman Sjahruddin ${ }^{3)}$ \\ 1) STIEM BONGAYA,MANAJEMEN KEUANGAN \\ Penulis Korespondensi: dfakrian@yahoo.com
}

\begin{abstract}
Tujuan utama penelitian ini adalah untuk memperoleh bukti empiris pengaruh Literasi Keuangan terhadapa keputusan invetsasi dengan perilaku keuangan sebagai variabel moderasi, pada mahasiswa Stiem Bongaya Makassar angkatan 2016. variabel-variabel dalam pneleitian ini yaitu (1) Literasi Keuangan (2) Perilaku Keuangan (3) Keputusan investasi .penelitian ini menggunakan metode analisis regresi sederhana dan regresi moderasi. Hasil penelitian ini menunjukkan bahwa Literasi Kuangan memiliki pengaruh terhadapa Keputusan Invetsasi dan Perilaku Keuangan memoderasi pengaruh Literasi Keuangan terhadapa Keputusan Invetsasi
\end{abstract}

Keywords: Literasi Keuangan, Perilaku Keuangan, Keputusan Investasi 


\section{PENDAHULUAN}

Investasi merupakan pengorbanan disaat sekarang dengan tujuan mendapatkan manfaat yang lebih besar dimasa yang akan datang (Haming dan Basalamah 2010). Untuk meminimalisir resiko investor harus rasional dalam mengahadapi pasar jual beli saham. Selain itu, investor harus memiliki ketajaman perkiraan masa depan perusahaan yang sahamnya akan dibeli atau dijual. Selain keterampilan dan ketajaman pengambilan keputusan investasi, seorang investor banyak di pengaruhi oleh perilaku.Perilaku disini merupakan perilaku keuangan dalam hal mengelolah keuangan yang disebut dengan financial literacy yang terlibat didalamnya.Financial literacy sebagai pengetahuan keuangan indivi juga merupakan kebutuhan dasar bagai setiap orang agar terhindar dari permasalahan keuangan. kesulitan keuangan muncul bukan hanya dilihat dari fungsi pendapatan saja, namun kesalahan dalam pengelolahan keuanagan (miss-management) seperti kesalahan penggunaan kredit dan tidak adanya perencanaan keuangan. Hal-hal tersebut terjadi karena kurangnya literasi keuangan serta pengalaman dalam diri individu tersebut. Oleh karena itu kita perlu memehami apa itu literasi kuangan. Literasi keuangan (financial literacy) merupakan suatu keharusan setiap individu agar terhindar dari masalah keuangan karena individu seringkali dihadapkan dengan Trade Off yaitu situasi dimana seseorang harus mengorbankan salah satu kepentingan demi kepentingan lainnya.

Chen dan Volpe (1998) juga mengungkapkan nahwa literasi dikalangan mahasiwa masih rendah, rendahnya literasi keuangan mahasiswa terjadi karena kurangnya edukasi personal finance di univesitas.Dalam penelitiannya Nidar dan Bestari (2012) juga menemukan bahwa literasi keuangan yang dimiliki mahasiswa masih dikatagorikan rendah, namun Nidar dan Bestari hanya menggunakan satu universitas sebagai sampel. Dalam penelitian lain juga menunjukkan bahwa literasi keuangan berpengaruh terhadap keputusan berinvestasi (Welly dkk., 2012) yang kemudian memperoleh bantahan pada studi yang dilakukan Ariani (2015) bahwa literasi keuangan tidak signifikan pengaruhnya terhadap keputusan investasi.
Bursa Efek Indonesia (BEI) sudah membuka peluang bagi para mahasiwa untuk berinvestasi dengan cara membuka galeri investasi di beberapa kampus yang ada di Indonesia dan sudah ada 400 universitas yang terdaftar di BEI sejak tahun 2018 (SumutInvest). Walupun di kampus sudah tersedia galeri investasi tetapi mahasiwa yang melakukan investasi masih terbilang sedikit, ini dikarenakan kurangnya literasi mahasiswa terhadap investasi dan perilku keuangan.

\section{TINJAUAN PUSTAKA}

Investasi menurut KBBI (Kamus Besar Bahasa Indonesia) adalah penanaman uang di suatu perusahaan atau proyek untuk tujuan memperoleh keuntungan. Menurut Sunariyah (2003:4) investasi adalah penanaman modal untuk satu atau lebih aktiva yang dimiliki dan biasanya berjangka waktu lama dengan harapan mendapatkan keuntungan dimasamasa yang akan datang. Jenis-jenis investasi terdiri dari (1) Invetasi langsung, Investasi langsung adalah pembelian langsung aktivaaktiva keuangan perusahaan (2) Investasi tidak langsung Yakni pembelian saham dari perusahaan investasi yang mempunyai portofolio aktiva-aktiva keuangan dari perusahaan-perusahaan lain.

Literasi keuangan menurut Otoritas Jasa Keuangan (2014) adalah pengetahuan, keterampilan, dan keyakinan yang mempengaruhi sikap dan perilaku untuk meningkatkan kualitas pengambilan keputusan dan pengelolahan keuangan dalam rangka mencapai kesejahteraan. Financial literacy memiliki sejumlah elemen yaitu (1) Keterampilan berhitung dasar, seperti kemampuan untuk menghitung tingkat pengembalian investasi, tingkat suku bunga utang, dan kemampuan aritmatika dasar (2) Pemahaman tentang manfaat dan risiko yang terkait dengan keputusan keuangan tertentu, termasuk pengeluaran, pinjaman, leverage dan investasi (3) Kemampuan untuk memahami konsep keuangan dasar, termasuk trade off antara risiko dan return, atribut utama dari berbagai jenis investasi dan produk keuangan lainnya, manfaat diversifikasi, dan nilai waktu dari uang (3) Kapasitas untuk mengetahui kapan harus mencari saran professional dan apa yang harus ditanyakan, dan kemampuan 
untuk memahami saran yang diberikan oleh penasihat profesional.

Menurut Shefrin (2000) behavior finance adalah studi yang mempelajari bagaimana fenomena psikologi mempengaruhi tingkah laku keuangan para pemain saham, Nofsinger (2001) mendefinisikan perilaku keuangan yaitu mempelajari bagaimana manusia secara actual berperilaku dalam sebuah penentuan keuangan ( a financial setting). Konsep perilaku keuang terbagi atas beberapa (1) Psikologi, Menurut Irham (2016), psikolgi merupakan ilmu penegtahuan yang membahas tentang tingka laku manusia sebagai individu dan kelompok serta hubungan keduanya dengan lingkungan secar terbuka maupun tertutup (2) sosiologi, Menurut Gunawan (2000), sosiologi adalah ilmu tentang cara berteman,berkawan,bersahabat,bergaul yang baik dalam masyarakat. Sosiologi merupakan pengetahuan kemasyarakatan yang tersusum dari hasil -hasil pemikiran ilmiah dan dapat dikontrol secara kritis oleh orang lain atau umum (3) keuangan, Menurut ensiklopedia ekonomi, keuangan (finance)mempelajari bagaiman individu, bisnis, dan organisasi meningkatkan, mengalokasi, dan menggunakan sumber daya moneter sejalan dengan waktu, dan juga menghitung risiko dalm menjalan proyek mereka.

\section{METODE PENELITIAN}

Subjek penelitian yaitu seluruh mahasiswa Stiem Bongaya Makassar angkatan 2016 dengan sampel 46

Motode analisi data dalam penelitian ini yaitu melalui validitas\&uji reliabilitas, uji asumsi klsik, uji regresi sederhana,uji moderasi,uji kelayakan model (uji F), uji koefisiensi regresi persial (uji T). Pengujian ini dilakukan melalui SPSS 23

Berdasarkan metode analisis tersebut, Hipotesis (Ha) yang akan di uji yaitu :

Ha1 : Literasi keuangan berpengaruh positif signifikan terhadap Keputusan Investasi

Ha2 : Perilaku keuangan memoderasi pengaruh literasi keuangan terhadap keputusan investasi

\section{HASIL DAN PEMBAHASAN}

Pengujian pertama yaitu uji validitas, dimana uji validitas digunakan untuk mengukur valid dan sahnya suatu kuesioner.
Tabel 1

Uji Validitas

\begin{tabular}{c|c|c|c|c}
\hline $\begin{array}{c}\mathrm{N} \\
\mathrm{o}\end{array}$ & Variabel & $\begin{array}{c}\text { Kode } \\
\text { Instrum } \\
\text { en }\end{array}$ & $\begin{array}{c}\text { Nilai } \\
\text { Persen } \\
\text { Correlati } \\
\text { an }\end{array}$ & $\begin{array}{c}\text { Keterang } \\
\text { an }\end{array}$ \\
\hline 1 & Literasi & $\mathrm{X} 11$ & 0,643 & valid \\
& $\begin{array}{c}\text { Keuang } \\
\text { an }\end{array}$ & $\mathrm{X} 12$ & 0,480 & Valid \\
& X13 & 0,714 & Valid \\
& (X1) & X14 & 0,607 & Valid \\
& Periku & X21 & 0,773 & Valid \\
& Keuang & X22 & 0,829 & Valid \\
& an & X23 & 0,871 & Valid \\
& (X2) & & & \\
3 & Keputus & Y11 & 0,724 & Valid \\
& an & Y12 & 0,690 & Valid \\
& Investas & Y13 & 0,756 & Valid \\
& i & Y14 & 0,724 & Valid \\
& (Y) & Y15 & 0,809 & Valid \\
\hline
\end{tabular}

Berdasarkan Tabel 1 dapat dilihat bahwa instrument penelitian yang terdiri dari item-item pertanyaan Literasi Kuangan (X1), Perilaku Keuangan (X2), Keputusan Investasi (Y) adalah valid. Hal ini di karenakan korelasi antara skor masing-masing pertanyaan dengan skor total besarnya di atas 0,30

Pengujian ke dua yaitu uji realibilitas, dimana uji realibilitas digunakan untuk menguji pertanyaan dalam kuesioner penelitian ini reliable dan dapat digunakan.

Tabel 2

Realibilitas

\begin{tabular}{c|c|c|c}
\hline No & Variabel & $\begin{array}{c}\text { Cronbach's } \\
\text { Alpha }\end{array}$ & Keterangan \\
\hline 1 & $\begin{array}{c}\text { Literasi } \\
\text { Keuangan } \\
(\mathrm{X} 1) \\
2\end{array}$ & 0,719 & Reliabel \\
Perilaku & 0,852 & Reliabel \\
Keuangan \\
$(\mathrm{X} 2)$ \\
$\begin{array}{c}\text { Keputusan } \\
\text { Investasi } \\
(Y)\end{array}$ & 0,795 & Reliabel \\
\hline
\end{tabular}

Beradasarkan Tabel 2 dapat dilahat bahwa nilai Cronbach's Alpha masing-masing variabel memiliki nilai lebih besar dari 0,60 . Hal ini menunjukkan bahwa semua pertanyaan dalam kuesioner penelitian ini reliable dan dapat di gunakan.

Pengujian ke tiga yaitu uji normalitas dengan uji statistik non-paremetik Kolmogorov-Smirnov (K-S). 
Tabel 3

Normalitas

One-Sample Kolmogorov-Smirnov Test

\section{Coefficients $^{\mathrm{a}}$}

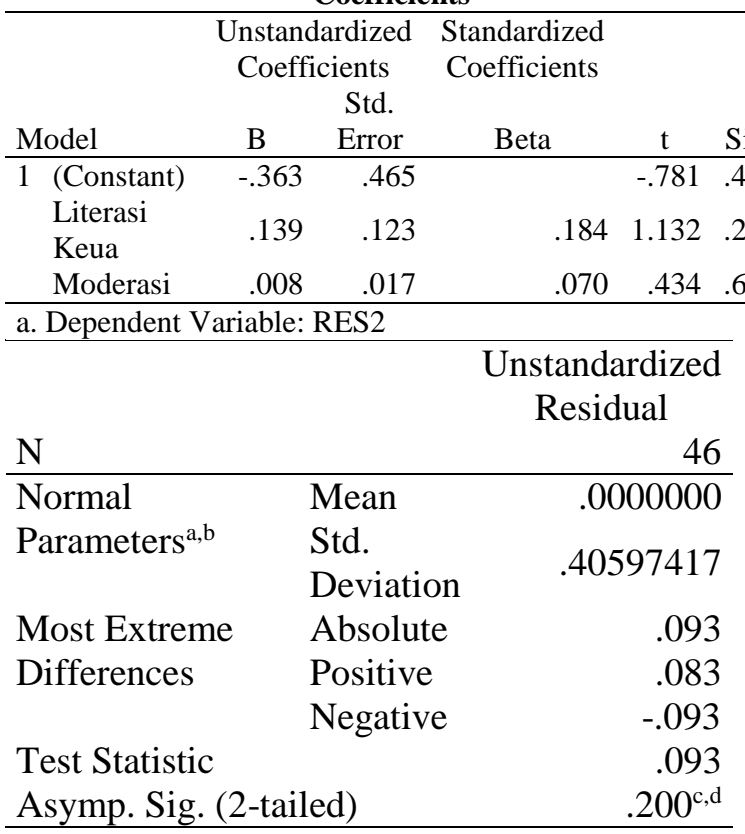

a. Test distribution is Normal.

b. Calculated from data.

c. Lilliefors Significance Correction.

$\mathrm{d}$. This is a lower bound of the true significance.

Berdasarkan Tabel 3 , nilai asymp. Sig. (2-tailed) 0,200 . Nilai ini lebih besar 0,05, apabila dibandingkan dengan kriteria yang ada, dan disimpulkan bahwa data dalam penelitian terdistribusi normal.

Pengujian ke empat yaitu uji multikolinearitas melalui nilai tolerance lebih besar dari 0,10 maka artinya tidak terjadi multikolinieritas terhadap data yang di uji. jika nilai VIF lebih kecil dari 10,00 maka tidak terjadi multikolinieritas terhadap data yang di uji

Tabel 4 Multikolineritas a. Dependent Variable: Keputusan Inves

Tabel di atas menunjukkan masingmasing variabel independen nilai tolerance lebih dari 0,10 dan lebih kecil dari 10,00 maka dapat disimpulkan tidak terjadi multikolinieritas.

Pengujian ke lima yaitu uji heterokedastisitas melalaui Glejser, dengan kriteria apabila nilai signifikan lebih besar dari 0,05 maka tidak terjadi heteroskedasitas, dan sebaliknya jika nilai signifikan lebih kecil dari 0,05 maka terjadi heteroskedastisitas.

Tabel 5

\section{Heteroskedasitas}

Tabel di atas menunjukkan masingmasing variabel independen nilai tolerance lebih dari 0,10 dan lebih kecil dari 10,00 maka dapat disimpulkan tidak terjadi multikolinieritas.

Pengujian ke enam yaitu uji koefisien determinasi $\left(\mathrm{R}^{2}\right)$ dan terbagi menjadi 2 yaitu. Uji koefisien determinasi $\left(R^{2}\right)$ yang pertama terkait dengan model regresi sederhana untuk Ha1, dengan hasil uji sebagai berikut.

Tabel 6

Uji Koefisien Determinasi $\left(\mathbf{R}^{2}\right)$ Model Summary

Std.

Adjusted Error of

$\mathrm{R} \quad \mathrm{R}$ the

Model $\mathrm{R}$ Square Square Estimate

\begin{tabular}{lllll}
\hline 1 & $.446^{\mathrm{a}}$ & .199 & .162 & .41331 \\
\hline
\end{tabular}

a. Predictors: (Constant), Perilaku.Keua,

Literasi.Keua

Tabel diatas menunjukkan bahwa adjusted R2 sebesar 0,162, yang artinya literasi keuangan dapat menjelaskan keputusan investasi sebesar 0,162 atau $16,2 \%$.

Uji koefisien determinasi $\left(\mathrm{R}^{2}\right)$ yang ke dua terkait model regresi moderasi untuk Ha2 dengan uji

\section{Coefficients $^{\mathrm{a}}$}

\section{Model Summary}

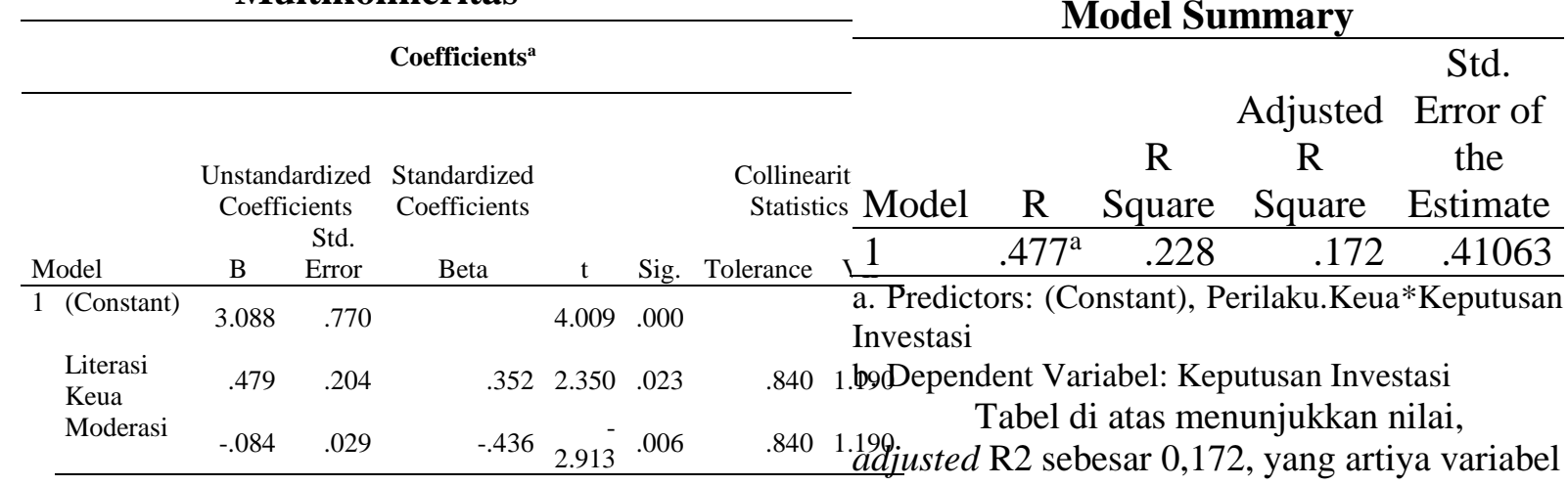


manajemen laba dapat menjelaskan keputusan investasi dengan semakin baik dengan adanya interaksi dari literasi keuangan dan perilaku keuangan. Hal ini dibuktikan dengan nilai adjusted $\mathrm{R}^{2}$ sebesar 0,172 atau $17,2 \%$.

Pengujian ke tujuh yaitu uji kelayakan model (uji F), dengan criteria apabila nilai sig. $<0,05$ maka Ha diterima. Hasil uji $\mathrm{F}$ sebagai berikut.

\section{Tabel 7}

\section{Uji Kelayakan Model (Uji F)}

Tabel diatas menunjukkan nilai sig. sebsar 0,01 dan apabila dimasukkan kedalam criteria yang ada, nilai sig. tersebut lebih besar dari 0,05 yang artinya Ha di tolak. Variabel independen yang ada dalam penelitian secara simultan tidak memepengaruhi keputusan investasi.

Pengujian ke delapan yaitu uji koefisien regresi persial (uji T), dengan criteria apabila nilai sig. $<0,05$ maka Ha diterima. Hasil ujinya

\section{Tabel 8}

\section{Uji Koefisien Regresi Persial (Uji T)}

\begin{tabular}{|c|c|c|c|c|c|}
\hline \multicolumn{6}{|c|}{ Coefficients $^{\mathrm{a}}$} \\
\hline \multirow[b]{2}{*}{ Model } & $\begin{array}{l}\text { Unstanc } \\
\text { Coeffi }\end{array}$ & $\begin{array}{l}\text { irdized } \\
\text { ients }\end{array}$ & $\begin{array}{l}\text { Standardized } \\
\text { Coefficients }\end{array}$ & & \\
\hline & $\mathrm{B}$ & $\begin{array}{l}\text { Std. } \\
\text { Error }\end{array}$ & Beta & $\mathrm{t}$ & Sig. \\
\hline 1 (Constant) & 3.088 & .770 & & 4.009 & .000 \\
\hline $\begin{array}{l}\text { Literasi } \\
\text { Keua }\end{array}$ & .479 & .204 & .352 & 2.350 & .023 \\
\hline
\end{tabular}

a. Dependent Variabel: Keputusan Investasi

Tabel diatas menunjukkan nilai sig. sebesar 0,023, maka Ha diterima atau Literasi Keuangan berpengaruh signifikan terhadap keputusan investasi. Hasil ini sesuai dengan penelitian sebelumnya yang dilakukan Welly, Welly and Kardinal, Kardinal and Juwita, Ratna (2012).

Hasil uji T yang kedua untuk Ha2 yaitu:

\begin{tabular}{|c|c|c|c|c|c|}
\hline \multirow[b]{3}{*}{ Model } & \multicolumn{3}{|c|}{ Coefficients $^{\mathrm{a}}$} & \multirow[b]{3}{*}{$\mathrm{t}$} & \multirow[b]{3}{*}{ Sig. } \\
\hline & \multicolumn{2}{|c|}{$\begin{array}{r}\text { Unstandardize } \\
\text { d Coefficients } \\
\text { Std. }\end{array}$} & $\begin{array}{l}\text { Standardize } \\
\mathrm{d} \\
\text { Coefficients }\end{array}$ & & \\
\hline & & $\begin{array}{l}\text { Std. } \\
\text { Error }\end{array}$ & Beta & & \\
\hline \multirow[t]{6}{*}{1 (Constant } & & & & 4.00 & .00 \\
\hline & 3.088 & .170 & & 9 & 0 \\
\hline & .479 & .204 & .352 & 2.35 & .02 \\
\hline & & & & 0 & 3 \\
\hline & -.084 & .029 & -.436 & 2.91 & $\begin{array}{r}.00 \\
6\end{array}$ \\
\hline & & & & 3 & \\
\hline
\end{tabular}

a. Dependent Variable: Keputusan Inves
Berdasarkan tabel diatas dengan nilai sig. yang telah di ketahui dapat disimpulkan bahwa Perilaku Keuangan memoderasi pengaruh literasi keuangan terhadap keputusan investasi.

Dalam penelitian Ftrianti, Baiq (2018) dengan penelitian yang berjudul Pengaruh Literasi keuangan, Perilaku Keuangan dan Pendapatan Terhadap keputusan Berinvestasi. Hasil dari penelitian ini menunjukkan bahwa financial literacy, perilaku keuangan dan pendapatan memiliki pengaruh dalam menentukan keputusan berinvestasi. Hal ini menjelaskan bahwa pengetahuan seseorang tentang mengelolah keuangan pribadinya menjadi faktor utama dalam menentukan keputusan sebuah investasi.

Adapun Khairunizam \& Yuyun Isbanah (2019) dalam penelitiannya yang berjudul pengaruh Financial Literacy dan Behavioral Finance Factors Terahadap Keputusan Investasi (Studi Terhadap Investor Saham Syariah Pada Galeri Investasi Syariah UIN Sunan Ampel Surabaya. Di dalam penelitiannya menunjukkan bahwa Financial Literacy tidak berpengaruh terhadap keputusan investasi pada investor saham syariah di Galeri Investasi Syariah UIN Sunan Ampel Surabaya. Overconfidance berpengaruh positif terhadap keputusan investasi pada investor saham Syariah di Galeri Investasi Syariah UIN Sunan

\begin{tabular}{|c|c|c|c|c|c|c|}
\hline \multicolumn{7}{|c|}{ ANOVAa } \\
\hline & & $\begin{array}{l}\text { Sum of } \\
\text { Squares }\end{array}$ & df & $\begin{array}{l}\text { Mean } \\
\text { Square }\end{array}$ & $\mathrm{F}$ & Sig. \\
\hline \multirow[t]{3}{*}{1} & Regression & 1.752 & 2 & .876 & 5.079 & $.010 \mathrm{~b}$ \\
\hline & Residual & 7.417 & 43 & .172 & & \\
\hline & Total & 9.169 & 45 & & & \\
\hline
\end{tabular}

a. Dependent Variable: Keputusan Inves

b. Predictors: (Constant), Moderasi, Literasi Keua

Ampel Surabaya. Risk perception tidakberpengaruh terhadap keputusan investasi pada investor saham Syariah di Galeri Investasi Syariah UIN Sunan Ampel Surabaya. Loss Aversion tidak berpengaruh terhadap keputusan investasii pada investor saham Syariah di Galeri Investasi Syariah UIN Sunan Ampel Surabaya. Herding berpengaruh positif terhadap keputusan investasi pada investor saham Syariah di Galeri Investasi Syariah UIN Sunan Ampel Surabaya. 


\section{KESIMPULAN DAN SARAN}

Berdasarkan hasil penelitian yang dilakukan dapat disimpulkan bahwa Literasi Keuangan berpengaruh signifikan terhadap keputusan investasi pada Mahasiswa STIEM BONGAYA angkatan 2016. Ini menunjukkan bahwa semakin baik Literasi Keuangan mahasiswa maka keinginanan untuk berinvestasi semakin tinggi. Hasil Uji Moderated Regression Analysis ditemukan bahwa perilaku keuangan mampu memoderasi di mana pengaruh yang diberikan memperkuat hubungan Literasi keuangan pada keputusan investasi masiswa STIEM BONGAYA angkatan 2016.

\section{REFERENSI}

Ariani, S. (2015). Pengaruh literasi keuangan, locus of control, dan etnis terhadap pengambilan keputusan investasi (Doctoral dissertation, STIE PERBANAS SURABAYA).

Dewi, I. M., \& Purbawangsa, I. B. A. (2018). PENGARUH LITERASI KEUANGAN, PENDAPATAN SERTA MASA

\section{BEKERJA}

TERHADAP PERILAKU KEPUTUSAN

INVESTASI. E-Jurnal Ekonomi dan Bisnis

Universitas Udayana, 7, 1867-1894.

Fitriarianti, B. (2018, February). Pengaruh Literasi Keuangan, Perilaku Keuangan Dan Pendapatan Terhadap Keputusan Berinvestasi. In Proseding Seminar Nasional Akuntansi (Vol. 1, No. 1).

Silvy, M., \& Yulianti, N. (2013). Sikap pengelola

keuangan dan perilaku perencanaan investasi keluarga di Surabaya. Journal

of

Business \& Banking (JBB), 3(1), 57-68.

Welly, W., Kardinal, K., \& Juwita, R. (2012).

Analisis Pengaruh Literasi Keuangan Terhadap Keputusan Investasi Di Stie Multi Data Palembang.

Pajar, R. C., \& Pustikaningsih, A. (2017). Pengaruh Motivasi Investasi dan Pengetahuan Investasi terhadap Minat Investasi di Pasar Modal pada Mahasiswa FE UNY. Jurnal Profita: Kajian Ilmu Akuntansi, 5(1).

Sudirman, S., \& Alhudhori, M. (2018). Pengaruh Konsumsi Rumah Tangga, Investasi Terhadap Pertumbuhan
Ekonomi di Provinsi Jambi. Ekonomis: Journal of Economics and Business, 2(1), 81-91.

Sumtoro, A., \& Anastasia, N. (2015). Perilaku Keuangan dalam Pengambilan Keputusan Berinvestasi Properti Residensial di Surabaya. Finesta, 3(1), 41-45.

Windayani, F. S., \& Krisnawati, A. (2019). Analisis Pengaruh Faktor Demografi Terhadap Literasi Keuangan Dan Keputusan Investasi Di Pasar Modal. eProceedings of Management, 6(1).

Taufiqoh, E., Diana, N., \& Junaidi, J. (2019). PENGARUH NORMA SUBJEKTIF, MOTIVASI INVESTASI, PENGETAHUAN INVESTASI, PERSEPSI RETURN DAN LITERASI KEUANGAN TERHADAP MINAT MAHASISWA BERINVESTASI SAHAM DI PASAR MODAL (Studi Empiris Pada Mahasiswa Akuntansi FEB UNISMA dan UNIBRAW di Malang). Jurnal Ilmiah Riset Akuntansi, 8(05).

Kartini, D., \& Si, M. (2018). Pengaruh Financial

Literacy dan Faktor Demografi Terhadap Keputusan Investasi Mahasiswa.

Wibowo, M. Y. P., \& Muharrami, R. S. (2018). PENGARUH LITERASI KEUANGAN DAN AKSES TERHADAP KEPUTUSAN BERINVESTASI DI PASAR MODAL SYARIAH (Studi Kasus: Investor di Galeri Investasi Bursa Efek Indonesia Fakultas Ekonomi dan Bisnis Islam IAIN Surakarta) (Doctoral dissertation, IAIN Surakarta).

Isbanah, Y. (2019). PENGARUH FINANCIAL

LITERACY DAN BEHAVIORAL FINANCE FACTORS TERHADAP KEPUTUSAN INVESTASI (STUDI TERHADAP INVESTOR SAHAM SYARIAH PADA GALERI INVESTASI SYARIAH UIN SUNAN AMPEL SURABAYA). Jurnal Ilmu Manajemen (JIM), 7(2). 